\title{
EVALUATION OF TRANSPORT MECHANISM OF CONTAMINANT PARTICLES IN SMALL WATER SYSTEMS IN POLAND
}

\author{
OCENA WYSTEPOWANIA MECHANIZMÓW TRANSPORTU OSADÓW \\ W MAŁYCH SYSTEMACH WODOCIĄGOWYCH W POLSCE
}

\begin{abstract}
The change in water quality in small water systems is strongly affected by sediment particles. Their transport, deposition and re-suspension due to variability in water demand has a significant impact on the change in water quality. Two significant mechanism of deposit transport and deposition i.e. turbophoresis and turbulent diffusion have been described in the literature. The paper presents the mechanisms of turbophoresis and turbulent diffusion. These phenomena have an impact on the quality of water in small water systems. The aim of the study is to propose procedures of identifying areas of mechanism of particle movement and their accumulation in small water system networks. Simulation of the flow of small water-pipe network at Niewiesz was used for the study. That water pipeline is situated in the central Poland. Many rural areas in Poland have a similar architecture. Modeling of movement of contaminant in close wall areas in pipelines is presented. The article presents the discussion concerning the areas where the mechanisms of turbophoresis and turbulent diffusion occur in the transport of solid particles in water supply systems. The relations between deposition and transporting of particles in turbulent flows depend on a number of parameters, including: particle size, localization of particles in the pipe (at given time), as well as the turbulence of flow. These parameters change depending on the water demand. The type of these changes depends on pipe diameters, material from which the pipes and the fittings are made, water demand and initial quality of water.
\end{abstract}

Keywords: turbophoresis, turbulent diffusion, water contaminant, EpaNet

\section{Introduction}

Water transported in water supply systems is very susceptible to all changes in water intake, as well as the processes of deposition and lifting from the pipeline walls the deposited particles transported with the flowing water. The most prevalent contaminants in water transport processes in pipelines are hydrated iron compounds and sand particles [1-3]. Transport and deposition of particles in pipelines is a very complex process. This results from the effects of many forces acting on flowing particles and from the complexity of the turbulent flow. An additional difficulty in modeling of contaminants transport in pipelines is

\footnotetext{
${ }^{1}$ Department of Chemical Engineering, Faculty of Process and Environmental Engineering, Lodz University of Technology, ul. Wólczańska 213, 90-924 Łódź, Poland, phone +48 692566 486, fax +48 42 636-56-63

*Corresponding author: 800433@edu.p.lodz.pl
} 
the extended structure of the water-pipe network and daily as well as seasonal variability of water intake.

Recently authors [1, 2, 4] have described two significant mechanisms of deposits transport and deposition, ie turbophoresis and turbulent diffusion. These mechanisms contribute to the change of water quality through transport of deposits particles. Therefore, it is of the utmost importance define them and determine their scopes of their occurrence.

Turbulent diffusion arises from the transport of local difference in concentration of contaminants by eddies, similarly to the transport of the momentum by the same eddies. Turbulent diffusion is significant when the particles inertia is low, as compared to viscosity forces transporting the particle in the flow and at a low turbulence of the flow. The process is by a few orders of magnitude more intense than molecular diffusion $[1,5]$.

Turbophoresis, from the point of view of the behavior of deposits in water supply system seems to be an equally important mechanism. It is defined as a mechanism of particles transport in the pipe during the turbulent flow [5]. This mechanism transfers the particle from the boundary of the transition layer into the areas of lower turbulence - mainly those close to the laminar sublayer and then deposits the particles on the pipe wall. The turbophoresis mechanism is influenced by a number of forces affecting the particles while they are transported. The result of the forces initiated by the eddies occurring in the turbulent flow is particles deposition on the whole surface of the pipe cross-section $[1,2,6$, 7]. It seems that knowing and understanding the mechanisms of the transport of contaminants particles flowing in water supply systems may contribute to improvement of the quality of transported water and maintenance of the pipeline's technical condition. Therefore, the aim of this study is to determine the areas and boundaries of the transport mechanisms (turbophoresis and turbulent diffusion) as exemplified by the small water-pipe network.

\section{Forces affecting the particles transport mechanisms}

To describe the mechanisms affecting the contaminants transport in the pipeline we should consider the forces affecting the particle in connection with the turbulent flow structure, and also determine the particle's velocity. Most of the flows in water-pipe are represented by turbulent flows. The particle in the water turbulent flow is affected by the following forces: inertial, gravitational, Saffman, Magnus, resistance of the medium, Brownian force, Basset force, as well as the virtual mass effect (this effect should be considered in the particle flow in fluids). The Basset memory force may be omitted $[1,8,9]$. The particle movement direction depends also on local eddies occurring in the flowing water, particle size and direction of rotation on its axis. The schematic effects of the above mentioned forces on the particle is presented in Table 1.

The Magnus force is a result of the particle rotation in relation to the surrounding liquid. We should herewith consider several cases of the particle rotation velocity. If the rotation velocity is lower than the local velocity of liquid, the Magnus force directs the particle towards the pipe wall. When the rotation velocity is higher than the local velocity, this force directs the particle to the flow core. The Magnus force is determined from the relation $[8,10]$ : 


$$
F_{m}=\frac{\pi}{8} \rho_{w} d_{p}^{3} \Delta v\left(\omega-\frac{1}{2} \frac{\vartheta u}{\vartheta y}\right)
$$

where:

$\rho_{w} \quad$ - water density water density $\left[\mathrm{kg} / \mathrm{m}^{3}\right]$,

$\omega \quad$ - angular velocity $[\mathrm{rad} / \mathrm{s}]$,

$d_{p} \quad$ - particle diameter $[\mathrm{m}]$,

$\Delta v \quad$ - velocity difference between the particle and surrounding liquid $[\mathrm{m} / \mathrm{s}]$,

$\vartheta u / \vartheta y$ - velocity gradient.

Table 1

Schematic presentation of the effects of Magnus and Saffman forces on particles transported in water pipelines [8]

\begin{tabular}{|c|c|c|c|c|}
\hline & \multicolumn{2}{|c|}{ Magnus force } & \multicolumn{2}{c|}{ Saffman force } \\
\hline Linear velocity of particle & dominant & negligible & negligible \\
\hline Angular velocity of particle & negligible & dominant & - & - \\
\hline Velocity of fluid & - & - & negligible & dominant \\
\hline Force direction & to the pipe wall & to the pipe axis & to the pipe wall & to the pipe axis \\
\hline
\end{tabular}

The Saffman lift force arises from the difference in the velocity of water under and over the particle. The Saffman force is more important for particles characterized by greater inertia. Furthermore, the direction of this force depends on the velocity difference in relation to the moving particle and the fluid which surrounds it. When the particle velocity is higher than the liquid velocity, the Saffman force lifts it towards the pipe wall. Similarly to the situation, when the particle velocity is lower than the liquid velocity, the particle will be lifted to the pipe axis. The factors decisive of the influence of the Saffman force on particles movement in the pipe are: the particle's considerable inertia and perpendicular gradient of velocity between the liquid and particle. The Saffman force may be described by the formula $[11,12]$ :

$$
F_{s}=1.62\left(\mu_{w} \rho_{w}\right)^{\frac{1}{2}} d_{p}^{2} \Delta v\left(\frac{\vartheta u}{\vartheta y}\right)^{\frac{1}{2}}
$$

where $\mu_{w}$ - dynamic viscosity of water [Pa s].

The resistance force assumes the following form [8]:

$$
F_{d}=\frac{C_{d} d_{p}^{2}|\Delta v| \Delta v \pi}{8}
$$

where $C_{d}$ - drag coefficient.

The virtual mass effect causes an increase in the particle inertia as well as a virtual increase in the particle mass. This phenomenon is caused by viscosity forces active in the boundary layer between the particle and fluid. This effect can virtually increase the particle mass and inertia to as much as $50 \%$. It is also important that the virtual mass phenomenon is 
negligible in the flow of fluid with lower density, for example air. However, this effect must be considered while analyzing the flow in water [13, 14].

For submicron particles the effect of Brownian force becomes significant. The Brownian force is described by the formula:

$$
n_{i}(t)=G_{i} \sqrt{\frac{\pi S_{0}}{\Delta t}}
$$

where:

$G_{i}$ - zero-mean, unit variance independent Gaussian random numbers,

$S_{0} \quad$ - Gaussian white noise random process with a spectral density,

$\Delta t$ - the time step used in the simulation.

The Brownian force $n_{i}(t)$ is modeled as a Gaussian white noise random process with a spectral density $S_{0}$ given as [15]:

$$
S_{0}=\frac{216 \cdot v_{L} \cdot k_{b} \cdot T}{\pi^{2} \rho_{w} d_{p}^{5} S^{2} C_{c}}
$$

where:

$v_{L}$ - kinematic viscosity of liquid $\left[\mathrm{m}^{2} / \mathrm{s}\right]$,

$k_{b} \quad$ - Boltzmann constant $[\mathrm{J} / \mathrm{K}]$,

$T$ - temperature $[\mathrm{K}]$,

$S$ - particle-to-fluid density ratio,

$C_{c}$ - Stokes-Cunningham slip correction factor.

Stokes-Cunningham slip correction factor is determined by the formula:

$$
C_{c}=1+\frac{2 \lambda_{F}}{d_{p}}\left(1.257+0.4 e^{-(1.1 d / 2 \lambda)}\right)
$$

where $\lambda_{F}$ - mean free path $[\mathrm{m}]$.

Analysis of the above presented forces (Saffman force, Magnus force, the force of the fluid resistance and Brownian force) allows to determine the dominance boundaries of the mechanisms of turbophoresis and turbulent diffusion for particles transport in water flowing in the pipeline.

\section{Turbophoresis and turbulent diffusion}

The determination of the boundaries of the effects of the above mentioned transport mechanisms of particles in pipelines would not be possible without determining the particles relaxation time. The particles relaxation time $\tau_{p}$ is represented by the relation between inertia and friction force. It indicates the time the particle needs to adjust its movement trajectory to changing flow conditions. This value may be calculated from the formula proposed by [4]:

$$
\tau_{p}=\frac{\rho_{p} d_{p}^{2}}{18 \rho_{w} v_{L}}(1+2.7 \mathrm{Kn})
$$

where:

$\rho_{p} \quad$ - particle density $\left[\mathrm{kg} / \mathrm{m}^{3}\right]$, 
$\mathrm{Kn}$ - the Knudsen number which indicates the ratio of the mean free path length to the particle size.

For particles flow in water the virtual mass effect should be taken into account. With this aim, density $\rho_{p}$ in Eq. (7) should be replaced by the expression $\left(\rho_{p}+0,5 \rho_{w}\right)$. According to $[1,4]$, for turbophoresis phenomena occurring in water the Knudsen number in Eq. (7) is negligible [1, 4, 14]. Taking into account above considerations, Eq. (7) assumes the following form:

$$
\tau_{p}=\frac{\left(2 \rho_{p}+\rho_{w}\right) d_{p}^{2}}{36 \rho_{w} v_{L}}
$$

Basing on relaxation time - Eq. (8), the form of dimensionless relaxation time may be defined and then the range of effects of transport mechanisms (turbophoresis and turbulent diffusion) can be described $[4,6,16]$ :

$$
\tau_{p}^{+}=\frac{u_{\tau}^{2} \tau_{p}}{v_{L}}
$$

Dynamic velocity is determined as follows:

$$
u_{\tau}=\left(\frac{\tau_{w}}{\rho_{w}}\right)^{\frac{1}{2}}=U\left(\frac{\lambda}{8}\right)^{\frac{1}{2}}
$$

where:

$$
\begin{array}{ll}
\tau_{w} & \text { - shear stress }\left[\mathrm{kg} / \mathrm{ms}^{2}\right], \\
U & \text { - water mean velocity }[\mathrm{m} / \mathrm{s}], \\
\lambda & \text { - friction factor. }
\end{array}
$$

For the dimensionless relaxation time $-\tau_{p}{ }^{+}<0.2$ the dominant particle transport mechanism is the turbulent diffusion. The transition area, for which $0.2<\tau_{p}{ }^{+}<20$, is characterized by changing particle transport mechanisms. The dimensionless relaxation time $\tau_{p}^{+}>20$ indicates that the dominant mechanism of particle transport is turbophoresis.

From the practical point of view, it is important to know the value of the dimensionless distance from the pipe wall $y^{+}$, for which the discussed mechanisms of deposits transport are observed. These mechanisms occur mainly in the areas close to the wall. As has been mentioned before, the area under significant impact of turbophoresis and turbulent diffusion occurs for dimensionless distance $y^{+}<40$ [4].

The dimensionless distance from the pipe wall is defined by equation:

$$
y^{+}=\frac{u_{\tau} y}{v_{L}}
$$

where:

$y \quad$ - distance from the pipe wall [m],

$u_{\tau} \quad$ - dynamic velocity $[\mathrm{m} / \mathrm{s}]$.

After introducing Eq. (8) in Eq. (9) we obtain the following form of the formula describing the effects of turbophoresis and turbulent diffusion depending on the transported particle diameter: 


$$
d_{p}=\sqrt{\frac{36 v_{L}^{2} \rho_{w} \tau_{p+}}{\left(2 \rho_{p}+\rho_{w}\right) u_{\tau}^{2}}}
$$

By introducing the critical values of dimensionless relaxation time $\tau_{p}{ }^{+}=0.2$ and $\tau_{p}{ }^{+}=20$ and substituting them to Eq. (12), the diameters of particles susceptible to the effects of turbulent diffusion and turbophoresis may be determined.

\section{Modeling the particle velocity}

It is a very complex process to estimate the particle velocity in the surrounding liquid. The difference of velocity $\Delta \mathrm{v}$ is a key parameter required for the determination of the forces affecting the particle transport mechanisms. The difference between the velocities decides about transport mechanism of particles in water pipelines:

$$
\Delta v=u-v
$$

where:

$u$ - velocity of the liquid surrounding the particle $[\mathrm{m} / \mathrm{s}]$,

$v \quad$ - particle velocity $[\mathrm{m} / \mathrm{s}]$.

The difference in velocity between the particle and surrounding liquid occur at the same time in Eq. (1) describing the Magnus force and in Eq. (2) defining the Saffman force.

The mechanisms controlling the particles movement in the area close to the wall comprise of particle lifting values by $y^{+}$from the laminar sublayer to the buffer zone and decide about depositing or lifting of particles. Taking into account definition of following forces (Saffman, Brown, resistance of the medium, virtual mass effect), Tian and Ahmadi proposed Eq. (14) which is the description of particles motion in the fluid flowing through the pipe [18]. Due to the size of particles occurring in pipelines, Brownian force may be omitted [4]. The Magnus force is by several orders of magnitude lower than the Saffman force value, so it is negligible. The Magnus force importance is noticeable only for larger particles in areas close to the wall (area $y^{+}<5$ ), but even then it affects the transport mechanisms insignificantly. Equation (14) is correct for areas close to the wall:

$$
\frac{d \mathrm{v}}{d t}=\frac{1}{\tau} \frac{C_{d} \operatorname{Re}_{p}}{24}(u-\mathrm{v})+F_{S} / m_{p}+g+n_{i}(t)
$$

where:

$\mathrm{v} \quad$ - particle velocity $[\mathrm{m} / \mathrm{s}]$,

$\tau_{p} \quad$ - relaxation time $[\mathrm{s}]$,

$\operatorname{Re}_{p}$ - particle Reynolds number [-],

$g \quad$ - acceleration of gravity $\left[\mathrm{m} / \mathrm{s}^{2}\right]$,

$m_{p} \quad$ - particle mass [kg],

$n_{i}(t)$ - the Brownian force $\left[\mathrm{m} / \mathrm{s}^{2}\right]$,

$F_{s} \quad$ - Saffman lift force [N].

The particle drag coefficient is determined as follows [18]:

for $\operatorname{Re}_{p}<1$

$$
C_{d}=\frac{24}{\operatorname{Re}_{p}}
$$


for $1<\operatorname{Re}_{\mathrm{p}}<400$

$$
C_{d}=\frac{24}{\operatorname{Re}_{p}}\left(1+0.15 \operatorname{Re}_{p}^{0.687}\right)
$$

The Reynolds number is determined by equation:

$$
\operatorname{Re}_{p}=\frac{d_{p}|u-\mathrm{v}|}{v_{L}}
$$

\section{Exemplary calculations}

Simulation of the flow of small water-pipe network at Niewiesz was used for the study. That water pipeline is situated in the central Poland. Many rural areas in Poland have a similar architecture. The pipes are made of PVC material and have a diameter from 90 to $220 \mathrm{~mm}$. Presented water system is typical for small cities and rural areas, therefore it is important to evaluate transport mechanisms of contaminant particles.

For water intake at Niewiesz the maximum daily water intake was registered in August 2002 in the amount of $483 \mathrm{~m}^{3}$, whereas the minimum one - in January 2000, amounting to $33 \mathrm{~m}^{3}$. According to the data, appropriate values of daily inequality coefficients were determined. It appeared that for the water-pipe network at Niewiesz it amounted to 1.39. The hourly variability of water demand was described using the histogram presented in Figure 1 [19].

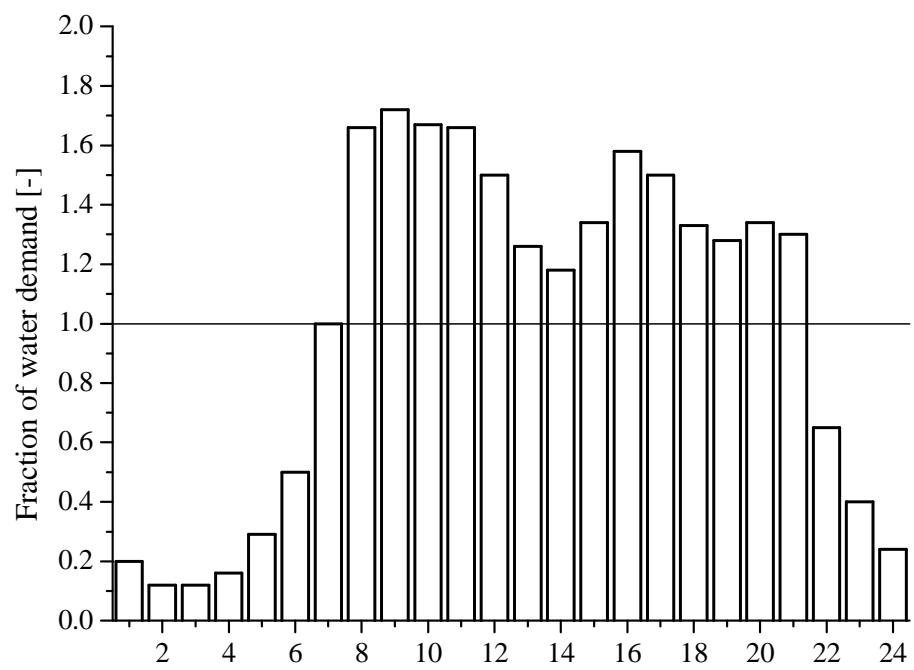

Fig. 1. Histogram of hourly water demands for Niewiesz water system

According to [1] diameters of deposited particles were assumed within the range from 5 to $100 \mu \mathrm{m}$, whereas the density of hydrated particles of iron $-1200 \mathrm{~kg} / \mathrm{m}^{3}$.

Calculations were made according to the simulation based on program EpaNet 2 [19]. EpaNet is a computer program developed by EPA Water Supply and Water Resources 
Division, which may be optionally copied and disseminated (which is public domain software). This program was created to facilitate the improvement of the hydraulic system effectiveness, thereby improving the quality of water supplied to the consumer through the distribution network. The Hybrid node-loop method was used [19] to solve the flow continuity equations in EpaNet program.

Figure 2 presents a diagram of the analyzed network and flow velocity in individual pipes, for the hour of maximum water demand (8:00 AM). As can be seen the flow rate in each section varies from $0.03 \mathrm{~m} / \mathrm{s}$ in the low demands areas to $1.5 \mathrm{~m} / \mathrm{s}$ in the main conduit network. For the lower water demand the flow velocity will be much lower. In Figure 2 pipe numbers correspond to the tubes of each pipelines. The ranges of velocity occurring in the hour of maximum water demand are presented in the Figure 2.

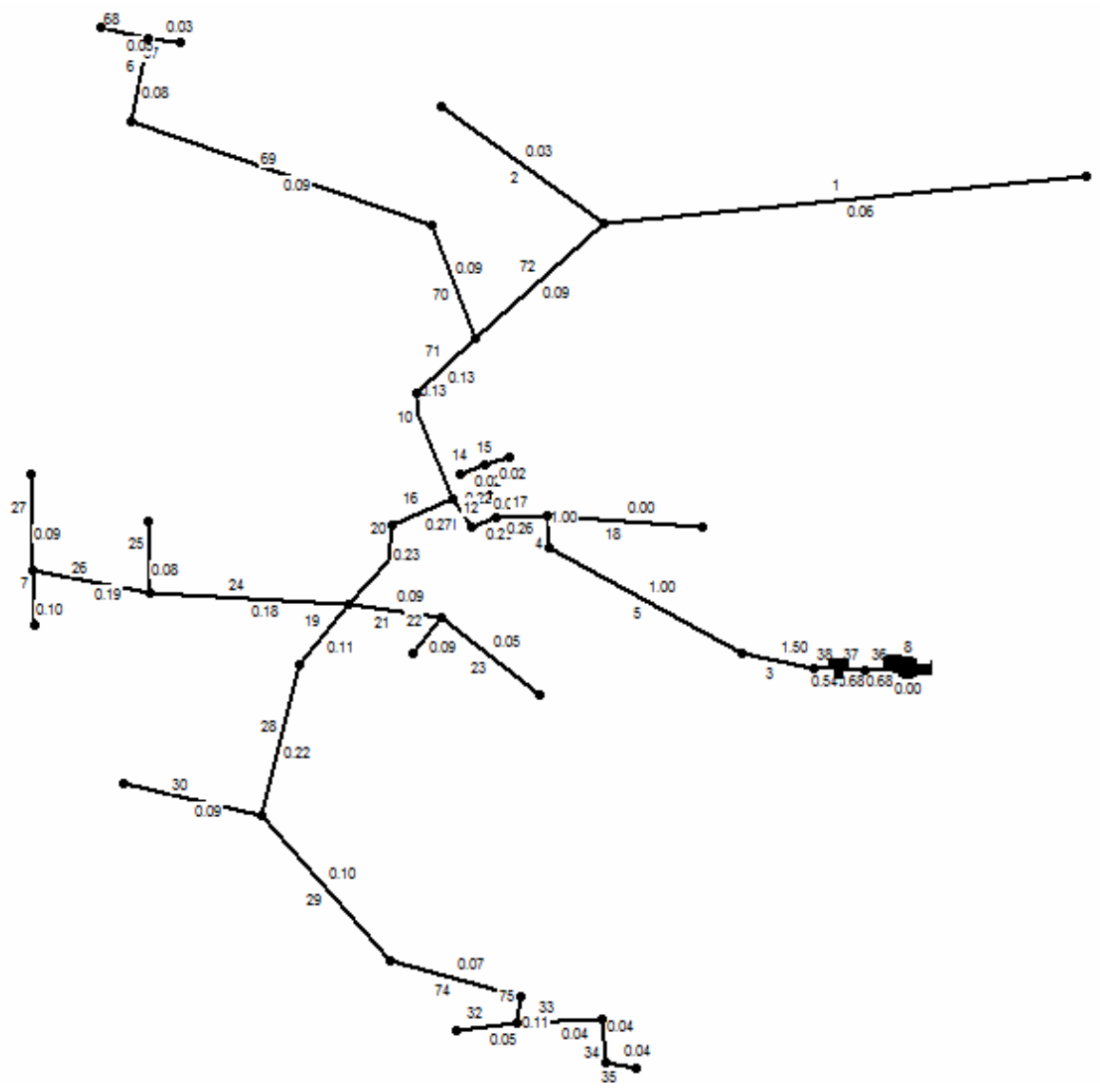

Fig. 2. Layout of water distribution network

The calculations or particles velocities in water network system were done for chosen five pipes: pipe 1, 2, 6, 10, 11 (indicated in Figure 2). Parameters of those pipes are presented in Table 2. 
Diameters and mean water velocity in chosen pipes

Table 2

\begin{tabular}{|c|c|c|c|c|}
\hline $\begin{array}{c}\text { Pipe } \\
\text { number }\end{array}$ & $\begin{array}{c}\text { Diameter } \\
{[\mathbf{m}]}\end{array}$ & $\begin{array}{c}U_{\max }[\mathbf{m} / \mathbf{s}] \\
\text { hour 8:00 }\end{array}$ & $\begin{array}{c}U_{\text {averge }}[\mathbf{m} / \mathbf{s}] \\
\text { hour 6:00 }\end{array}$ & $\begin{array}{c}\boldsymbol{U}_{\min }[\mathbf{m} / \mathbf{s}] \\
\text { hour 2:00 }\end{array}$ \\
\hline 1 & 0.11 & 0.06 & 0.04 & 0 \\
\hline 2 & 0.11 & 0.03 & 0.02 & 0 \\
\hline 6 & 0.09 & 0.08 & 0.05 & 0.01 \\
\hline 10 & 0.16 & 0.13 & 0.08 & 0.01 \\
\hline 11 & 0.215 & 0.22 & 0.13 & 0.02 \\
\hline
\end{tabular}

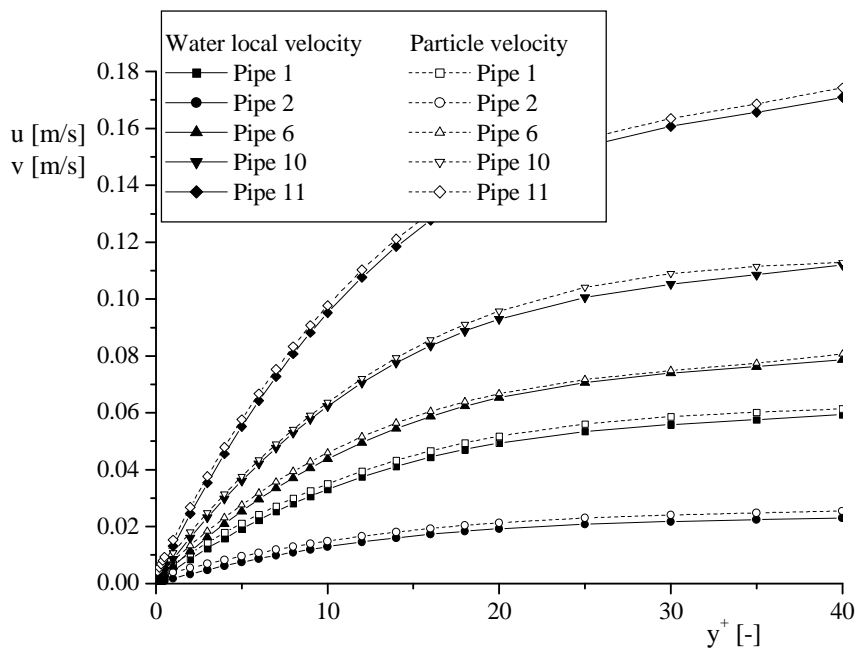

Fig. 3. The influence of dimensionless distance from the pipe wall $y^{+}$on water local velocity $u$ and particle velocity $v$ for the maximum water demand hour (8:00 AM)

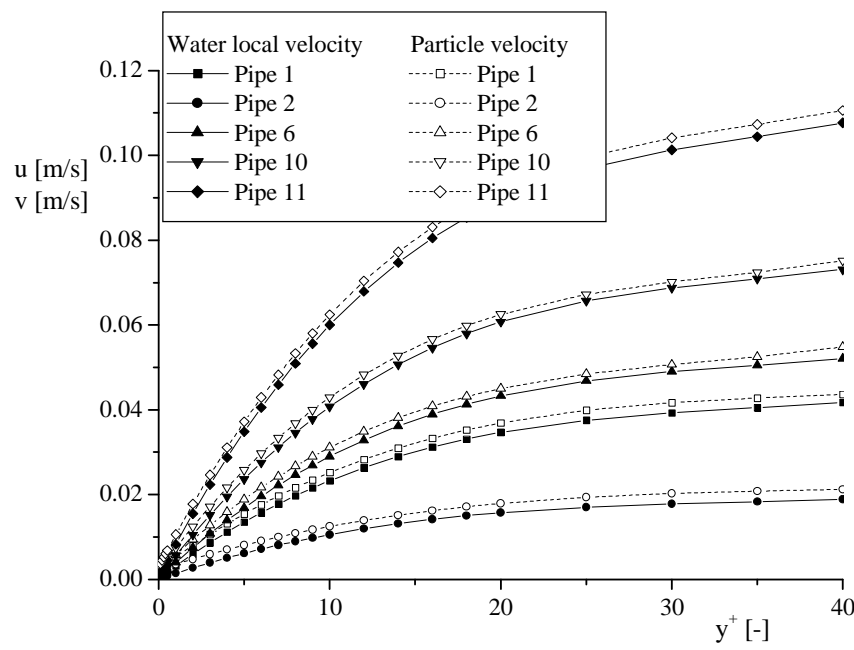

Fig. 4. The influence of dimensionless distance from the pipe wall $y^{+}$on water local velocity $u$ and particle velocity $v$ for the mean water demand hour (6:00 AM) 


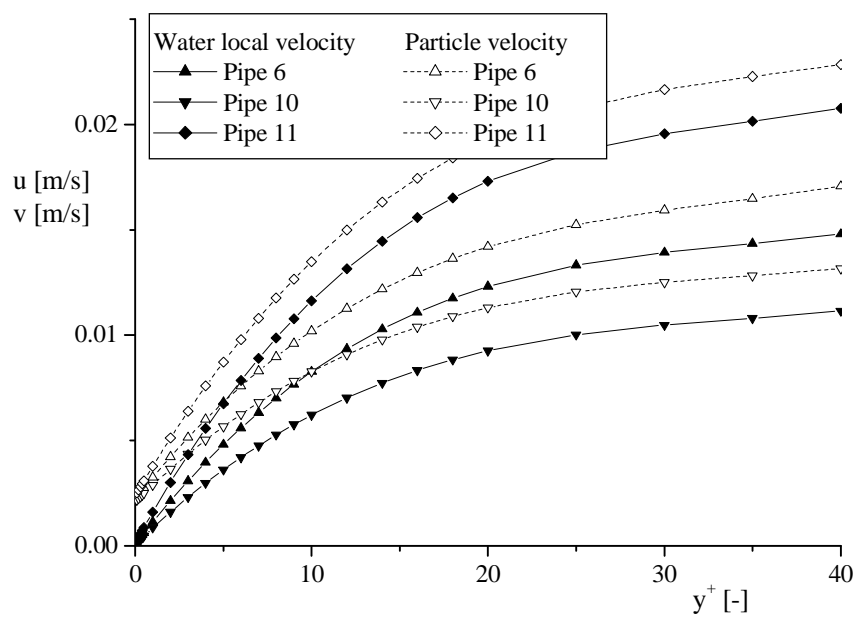

Fig. 5. The influence of dimensionless distance from the pipe wall $y^{+}$on water local velocity $u$ and particle velocity $v$ for the minimum water demand hour (2:00 AM)

The iteration method was used for determination of particles velocity. Calculation of mean water velocities (at the maximum water demand hour 8:00 AM, mean water demand hour 6:00 $\mathrm{AM}$ and for the minimum water demand hour 2:00 AM), assumed particle diameter equal to $50 \mu \mathrm{m}$, were done. The figures presented a statement drawn up for several pipes from Niewiesz water-pipe network for simulation hours 8:00 AM, 2:00 AM, and the mean daily water demand hour 6:00 AM.

Figures 3 to 5 present the particles velocities and local water velocities in the area close to the wall and transition zone, ie for $y^{+}<40$. Particles velocity is higher by approx. 10 to $20 \%$, as compared to the fluid local velocity. For the hours of increased flow, the particle velocities are similar to local velocities in the flow. For the minimal flow presented in figure 3 , the water flow was registered only in a part of the pipes because of very low water demand. There is no flow at the minimal water demand hour for pipes 1 and 2. It is worth nothing that the dimensionless distance $y^{+}$corresponds to the different value of dimensional distance $y$ depending on the liquid flow velocity $U$. At insignificant flow velocities the turbulent diffusion area may comprise the pipe's entire cross-section. The distance of the mentioned mechanisms changes due to the changing velocity of the flow $y^{+}=40$ occurs at close distance from the wall for flows characterized by high velocity.

The particle velocity determined in this way allows determining the forces affecting the transport mechanisms: turbophoresis and turbulent diffusion. We should notice that correctness of calculations will be satisfactory for areas close to the wall. Therefore, at insignificant velocities of the flow the turbulent diffusion area may cover almost the whole cross-section of the pipe.

\section{Localization of turbulent diffusion and turbophoresis in water system network}

Having the defined parameters, i.e. the particle velocity $\mathrm{v}$ and dimensionless relaxation time $\tau_{p}{ }^{+}$, we may determine which transport mechanism at a given place is most significant 
for a small water supply system. Analyzing the hour of maximum water demand (8:00 AM), we may state that the dominant transport mechanism is the turbulent diffusion, however for several pipes occur a transition area Figure 6 presents the particle's dimensionless relaxation times for average velocities for the hour of the greatest water demand. The calculations were performed for particle diameters $d_{p}=25,50$ and $100 \mu \mathrm{m}$. The straight line in Figure 6 is the border between the transport mechanisms of particles in the pipeline. The dominating transport mechanism of particles is represented by turbulent diffusion below this boundary line whereas a transition region between turbulent diffusion and turbophoresis occurs above it. For particles with diameter larger than $50 \mu \mathrm{m}$, the transition area is achieved already with low flow velocities, however for small particles even at high velocities the turbulent diffusion remains the main transport mechanism. Concluding, we can expect that deposition of particles will occur mainly in the lower half of the pipe's cross-section. The turbophoresis seldom appears in case of the maximum intake hour for the maximum hour water demand and finally, we can say that for hours and days of lower intakes it will not occur at all.

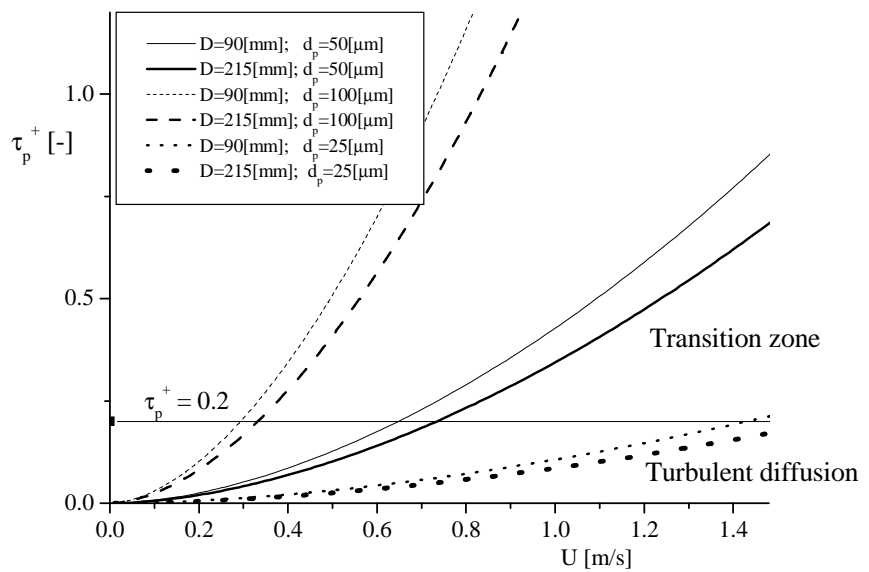

Fig. 6. Relaxation times for particles respective diameters $d_{p}$ and pipe diameter

As can be seen in Figure 6 the occurrence of transition area for small particles is virtually impossible even at high flow rates. For small water supply systems, particles with diameter $d_{p}<25 \mu \mathrm{m}$ will be transported by turbulent diffusion. Particles with small diameters undergo the turbulent diffusion process even at higher flow velocities. Particles with a diameter $d_{p}=50 \mu \mathrm{m}$ will enter the transitional region at velocity of about $0.7 \mathrm{~m} / \mathrm{s}$, which occurs rarely in real water flow in the pipe. However, for large particles with diameter $d_{p}=100 \mu \mathrm{m}$ transition zone is obtained at relatively low flow velocities. This may result from the particle's greater inertia. Concluding, for small water system networks, the main transport mechanism is the turbulent diffusion.

\section{Conclusions}

The article presents the discussion concerning the areas where the mechanisms of turbophoresis and turbulent diffusion occur in the transport of solid particles in water supply 
systems. The observations made herein indicate that the relations between deposition and transporting of particles in turbulent flows depend on a number of parameters, including: particle size, localization of particles in the pipe (at given time), as well as the turbulence of flow. These parameters change depending on the water demand. The type of these changes depends on pipe diameters, material from which the pipes and the fittings are made, water demand and initial quality of water. The possibility to characterize the contaminant particles behavior in the turbulent flow is important for predicting the areas where deposits may be deposited or lifted, and then for effective planning of periodical flushing of the pipeline. We should be aware of the existing difficulties in the description of the mechanisms of contaminant particles transport in pipe water. They include: availability of daily and seasonal distributions of water demands, precise analysis of the type and size of particles as well as the difficulties in the turbulent flow modeling. Therefore, the description of the mechanism of contaminant particles transport presented in the article seems to be very useful for the description of these phenomena in small water-pipe networks, because the adopted calculation methods yield satisfactory precision within the low turbulence flows, ie the flows which usually occur in small water-pipe networks.

\section{References}

[1] van Thienen P, Vreeburg JHG, Blokker EJM. Radial transport processes as a precursor to particle deposition in drinking water distribution system. Water Res. 2011;45:1807-1817. DOI:10.1016/j.watres.2010.11.034.

[2] Vreeburg JHG, Boxall JB. Discolouration in potable water distribution systems: review. Water Res. 2007;41:519-529. DOI: 10.1016/j.watres.2006.09.028.

[3] Vreeburg JHG, Scjippers D, Verberk JQJC, van Dijk JC. Impact of particles on sediment accumulation in a drinking water distribution system. Water Res. 2008;42:4233-4242. DOI:10.1016/j.watres.2008.05.024.

[4] Young J, Leeming A. A theory of particle deposition In turbulent pipe flow. J Fluid Mech. 1997;340:129-159. DOI: 10.1017/S0022112097005284.

[5] Guha A. A unified Eulerian theory of turbulent deposition to smooth and rough surfaces. J Aero Sci. 1997;28(8):1517-1537. DOI: 10.1016/S0021-8502(97)00028-1.

[6] Zanoun E, Durst F. Evaluating the law of the wall in two-dimensional fully developed turbulent pipe flows. Phys Fluids. 2003;15(10):3079-3088. DOI: 10.1063/1.1608010.

[7] Zanoun E, Durst F, Bayoumy O, Al-Salaymeh A. Wall skin friction and mean velocity profiles for fully developed turbulent pipe flows. Exp Therm Fluid Sci. 2007;32:249-261. DOI: 10.1016/j.expthermflusci.2007.04.002.

[8] Zhu HP, Zhou ZY, Yang RY, Yu AB. Discrete particle simulation of particulate systems: theoretical developments. Chem Eng Sci. 2007;62:3378-3396. DOI: 10.1016/j.ces.2006.12.089.

[9] Zou XY, Cheng H, Zhang CL, Zhao YZ. Effects of the Magnus and Saffman forces on saltation trajectories of sand grain. Geomorphology. 2007;90:11-22. DOI: 10.1016/j.geomorph.2007.01.006.

[10] Rubinow SI, Keller JB. The transverse force on spinning sphere moving in a viscous fluid. J Fluid Mech. 1961;11:447-459. DOI: 10.1017/S0022112061000640.

[11] Saffman PG. The lift of on small sphere in a slow shear flow. J Fluid Mech. 1965;22(2):385-400. DOI: 10.1017/S0022112065000824.

[12] Saffman PG. Corrigendum to "The lift on a small sphere in a slow shear flow". J Fluid Mech. 1968;31,624-624. DOI: 10.1017/S0022112068999990.

[13] Odar F. Verification of proposed equation for calculation of forces on a sphere accelerating in a viscous fluid. J Fluid Mech. 1966;25:591-592. DOI: 10.1017/S0022112066000272.

[14] Odar F, Hamilton W. Forces on sphere accelerating in a viscous fluid. J Fluid Mech. 1964;18(2):302-314. DOI: $10.1017 /$ S0022112064000210.

[15] Li A, Ahmadi G. Dispersion and deposition of spherical particles form point sources in a turbulent channel flow. Aero Sci Techn. 1992;16:209-226. DOI: 10.1080/02786829208959550. 
[16] Guha A. Transport and deposition of particles in turbulent and laminar flow. Ann Rev Fluid Mech. 2008;40:311-341. DOI: 10.1146/annurev.fluid.40.111406.102220.

[17] Tian L, Ahmadi G. Particle deposition in turbulent flows - comparisons of different model predictions. J Aero Sci. 2007;38:377-397. DOI: 10.1016/j.jaerosci.2006.12.003.

[18] Hinds WC. Aerosol Technology: Properties, Behavior, and Measurement of Airborne Particles. New York: Wiley; 1984.

[19] Rossman LA. EpaNet 2 Users Manual, Water Supply and Water Division National Risk Management Research Cincinnati, OH 45268, Laboratory Office of Research and Development U.S. Environmental Protection Agency 2000. EPA/600/R-00/057.

\title{
OCENA WYSTĘPOWANIA MECHANIZMÓW TRANSPORTU OSADÓW W MALYCH SYSTEMACH WODOCIĄGOWYCH W POLSCE
}

\author{
${ }^{1}$ Katedra Inżynierii Chemicznej, Wydział Inżynierii Procesowej i Ochrony Środowiska, Politechnika Łódzka
}

\begin{abstract}
Abstrakt: Na zmianę jakości wody w sieciach wodociągowych wpływają cząstki osadów obecnych w przewodach. Ich transport, osadzanie i ponowne wprowadzanie powodowane są zmiennością zapotrzebowania na wodę, mają więc znaczny wpływ na zmianę jakości wody. W literaturze zostały opisane dwa mechanizmy transportu i depozycji cząstek - turboforeza oraz turbulentna dyfuzja. Artykuł prezentuje występowanie obszarów mechanizmów turboforezy i turbulentnej dyfuzji na przykładzie małych sieci wodociągowych. Wymienione zjawiska mają wpływ na zmianę jakości wody w systemach wodociągowych. Celem pracy było zaproponowanie procedury identyfikacji mechanizmów transportu cząstek oraz ich akumulacji w małych sieciach wodociągowych. W tym celu wykorzystano symulacje małej sieci wodociągowej w miejscowości Niewiesz. Wodociąg ten umiejscowiony jest w centralnej części Polski. Jest to układ wodociągu typowy dla zabudowy wiejskiej. Artykuł prezentuje mechanizm turbulentnej dyfuzji oraz turboforezy, a także modelowanie transportu cząstek w obszarach przyściennych rur wodociągowych. Związek pomiędzy depozycją i transportem zależny jest od wielu parametrów: rozmiaru cząstki, aktualnego miejsca przebywania cząstki (w danej chwili) w przewodzie oraz od turbulencji przepływu. Parametry te ulegają zmianie na skutek zmian w poborze wody. Rodzaj tych zmian zależy od średnicy rury, materiału rury i armatury, zapotrzebowania na wodę oraz jakości początkowej wody.
\end{abstract}

Słowa kluczowe: turboforeza, turbulentna dyfuzja, zanieczyszczenia w wodzie, EpaNet 